\title{
LEGALIZATION OF NON-TRADITIONAL MARRIAGES AS A FACTOR UNDERMINING THE MORAL BASIS OF THE FAMILY AND LEADING TO THE REJECTION OF CHRISTIAN VALUES
}

\author{
Dina Viktorovna Alontseva ${ }^{1}$ \\ Olga Anatolyevna Lavrishcheva ${ }^{2}$ \\ Alexandra Vladimirovna Plotnikova ${ }^{3}$ \\ Yulia Nikolaevna Kirichenko ${ }^{4}$ \\ Alexey Vladimirovich Medvedev ${ }^{5}$
}

\begin{abstract}
The goal of this research article is to demonstrate that nontraditional marriages not only undermine the moral basis of the institution of the family, and lead to the rejection of traditional values. In order to examine this problem, comparative analysis was
\end{abstract}

chosen as the main research method. Through the exploration of international experience and comparing legal norms, repeating the same mistakes in the area of domestic law and judicial practice can be avoided. This approach also facilitates the assessment of the effectiveness of

${ }^{1}$ Candidate of Legal Sciences, Associate Professor, Head of the Chair of Theory and History of State and Law, Bunin Yelets State University, Yelets, Russia, dina.alontseva@yandex.ru, ORCID ID 0000-0003-2486-9248.

${ }^{2}$ Candidate of Legal Sciences, Associate Professor, Chair of Civil Proceedings and Arbitration, Bunin Yelets State University, Yelets, Russia, olgalavrishcheva@yandex.ru, ORCID ID 0000-0003-4012-5505

${ }^{3}$ Candidate of Legal Sciences, Associate Professor, Department of State and Law Theory and History, Southwest State University (SWSU), Kursk, Russia, alexandraplotnikova@bk.ru, ORCID ID 0000-0002-0125-8762

${ }^{4}$ Candidate of Legal Sciences, Associate Professor, Senior Lecturer at the Departmemt of Tactical and Special Training Federal State Public Educational Establishment of Higher Training «Belgorod Law Institute of Ministry of the Internal of the Russian Federation named after I.D. Putilin», Belgorod, Russia, yuliankirichenko@yandex.ru, ORCID ID 0000-0001-6309-1067

${ }^{5}$ Candidate of Psychological Sciences, Professor at the Department of Psychology and Pedagogy, Federal State Public Educational Establishment of Higher Training «Belgorod Law Institute of Ministry of the Internal of the Russian Federation named after I.D. Putilin», Belgorod, Russia, alexeyn.medvedev@yandex.ru, ORCID ID 0000-0002-4236$131 \mathrm{X}$ 
solving various problems of law enforcement associated with the institutions of marriage and as a consequence, family in modern society. Additionally, the authors employed some other general and private scientific methods. Based on the findings of this work, the following conclusions were drawn: non-traditional marriage is a relationship in which the number of participants, their gender, the method of marriage registration, as well as the method of choosing a partner differ from the generally accepted standard of "the man and the woman" to meet sexual interests and needs of the participants. It is noteworthy that family is the basis of the state, national identity, and cultural development. Without a family in its traditional sense, it is impossible to preserve traditions and to pass them on from one generation to another. Therefore, it is imperative for us and our legislators to seriously consider the legalization of the concept of nontraditional marriages so that they are prohibited and the individuals who are looking to enter into such marriages are persecuted, since these newfangled Western trends are aimed at the destruction of state values and the inexorable degradation of the state itself.

\section{Introduction}

The changes in Russia's political, economic, and social system have led to large-scale transformations in many areas of life. In this context, the continuing processes of globalization have contributed to the formation of a post-industrial society characterized by radical changes in traditional values and ethical ideals. In turn, these transformations have greatly influenced professional, moral, psychological, aesthetic, and family relationships of the genders, which has negatively affected the very fabric of family values.

Nowadays, the family remains the most important socially significant institution that requires close attention and support from the state. Recently, the development of information and communication systems (ICT) has catalyzed a nefarious, massive propaganda of new values, aiming to promote such a distorted form of family relations as cohabitation among Russian citizens. In addition, such concepts as abortion or a forced action on an unborn child have easily taken root in modern 
society. At the same time, recent European family trends entailing the promulgation of same-sex marriages and the adoption of children by such families also have a noticeable influence on Russian society. All these changes are systematically undermining and uprooting centuries-old family values and traditions of children upbringing in Russia. For this reason, the preservation of marriage and family values today is a pressing issue that modern Russian society should be concerned about.

At present, Russia is witnessing a crisis in the institution of the family. The number of marriages in our country has decreased. The underlying reasons for this should be sought not only in the external economic circumstances of the life of a family, but also in the personal features, the loss of spiritual foundations, of the values that hold the family together. It was the rejection of the holiness of the marriage bond that provoked the crisis of the modern institution of marriage and family relations in Russia (a considerable number of divorces, the emergence of non-traditional family models: civil marriage, guest marriage, childfree, and partner swapping). The reasons for this are the increasing popularity of liberal values, in particular, unmarried sex, homosexuality, and the exaggerated idea of sexual equality. As a result, the individuals have lost their moral integrity, which leads to the alienation of man in society and their further degradation.

In Russia, there has been an acute discussion about the legalization of same-sex marriages since the 2000s. This is because same-sex couples living in Russia began to refer to the global experience and attempted to register their relationship. The first attempts to legalize same-sex marriages in Russia were made in Moscow: "On January 18, 2005 the Savelovsky registry office of Moscow registered the application for entering into a same-sex marriage between Yabloko's parliament member Edward Murzin and the editor-in-chief of the gay magazine "Queer" Eduard Mishin." By this, they publicly revealed their sexual orientation, and their attempt of a marriage was an appeal to the Russian society to resolve this issue at the legislative level.

Today, researchers air their ideas about further development of same-sex marriages in Russia. President 
of the Russian Federation V.V. Putin (2013) expressed his dissatisfaction with Western attempts to eliminate the differences between traditional and same-sex families, and Patriarch Kirill called the homosexual union "the destruction of the nation" (Yakovleva, 2013). Most researchers exploring this issue believe that in the future the legalization of such marriages in Russia is impossible since it will not find support among most Russians.

However, some people claim that it is possible, but in the distant future. For example, sociologist Alexander Novikov (2008) said: "I predict that it is quite a while until samesex marriages can be registered in Russia." Vitaly Milonov (the author of St. Petersburg law "On the prohibition of gay propaganda") questions such statements and notes that homosexual families will never be recognized in Russia.

Igor Kochetkov, one of the leaders of the LGBT network of the Russian interregional social movement aiming at the protection of the rights and social adaptation of sexual and gender minorities, has the opposite opinion. He says, "Within less than 20 years, the main European countries will recognize marital equality for all, regardless of their sexual orientation. This is a common process, not a parallel one, and Russia will be involved in it. In a free discussion, we can come to a consensus. I believe that the issue of legalizing same-sex marriage in Russia is a matter of time and public discussions" (Kochetkov, 2013).

We see that this issue currently remains debatable in the Russian society. Perhaps in the future, supporters and opponents of the legalization of samesex marriage will reach an agreement. However, according to the forecasts of experts, this will not happen soon.

As for the recognition of samesex marriages throughout the world, we can highlight two trends. Firstly, there are countries in which gay marriage has been legalized (Greenland, Canada, USA, Argentina, Uruguay, part of Mexico, Iceland, Finland, Sweden, Norway, Britain, France, Belgium, Spain, Portugal, South Africa, Japan, Malta, Zealand, and Colombia). Secondly, some countries have legalized same-sex civil partnerships and unions (Germany, Czech Republic, Hungary, Switzerland, Greece, Croatia, Cyprus, 
and Estonia). Equating such, a marriage to an official one poses some problems: the identification of marriage as a legal and social institution, blurred family roles, the time of their beginning and expiration, the range of rights and obligations of spouses.

Same-sex marriage is just a form of marriage and family relations. The problem is much more serious since marriage and family relations are changing, and not for the better. In this paper, the definition of "non-traditional marriage" denotes all kinds of relationships based on hedonism and sexual freedom. It should be noted that this term is not used in international and national legislation, despite its wide application.

In our opinion, non-traditional marriage is a deviation from Christian norms, and it is anti-religious. Such a non-traditional marriage should be considered not as a union of a man and a woman aimed at starting a family and procreation, but as a fake, that devalues the traditional purpose of the institution of the family and marriage.

The seventh commandment of the synodal translation of the Bible is: "Thou shalt not commit adultery." The same commandment can be called the Christian principle of sexual morality as it emphasizes the needs of human as a biological being for his internal moral purity.

Christian norms pay a lot of attention to the essence of human nature and its manifestations. Christian doctrine is focused on man, his spirituality, education, and morality. It has a negative attitude to all manifestations of the sinful nature of the human. From the Apostolic Age, Christian ideas about sexuality did not contain the definition of the legal nature of marriage customary for us. They regarded all non-traditional forms of sexual relations as adultery, identifying them as sinful. For example, Jewish historian Josephus Flavius condemned sodomy and compared this act to sex with a menstruating woman and bestiality, emphasizing that "Moses forbade sexual relations with a menstruating woman, bestiality and sodomy, pointing to all the shame of such crimes" (Flabius, 1544).

The Russian Orthodox Church has a pronounced negative attitude to these phenomena and gives an explicit theological answer to the problem we are studying. Unfortunately, the sexual 
madness that affects many people, regardless of their age, gender, nationality, religion, social status, is not currently being treated. This ailment can be healed only through religion, the theological dogmas and rules that should be followed and learned. We should turn to the teaching of the Holy Apostles, which protects the moral standards of human coexistence.

The Russian Orthodox Church has always seen the marriage and the family not only as a union of two people formed for obtaining mutual benefits and giving birth to children. In the story of the creation of humankind, we see that God did not just create man as an individual. Humanity was created as a family in which there were a man and a woman, and this marriage union was completed by their relationship with God and the potential to be creators of their own kind - childbearing.

"For Christians, marriage has become not just a legal contract, a means of procreation and satisfaction of fleeting bodily needs, but, according to St. John Chrysostom, the sacrament of love, the eternal union of spouses with each other in Christ. Initially, Christians sealed marriage with a church blessing and joint participation in the Eucharist, which was the oldest form of the sacrament of marriage" (Official site Pravoslavie.ru, 2017). In other words, in the Christian tradition, the family is a small church with God and man.

Thus, the family as a home church is a single organism in which members find mutual understanding based on the laws of morality and mutual love, where family values are formed and passed on from generation to generation. Such an approach aims to create a healthy civic position through piety, the right attitude not only towards one's nearest and dearest, but also to the whole nation and society. To overcome the crisis of the institution of the marriage and family, one should turn to Christian values, which have a long history. They will help strengthen the family and will become the key to improving family relations in Russia. The Church taught in the past and still teaches the true principles of building the marriage and family. For many centuries, it has been instructing to have a family and build it according to the Word of our Lord Jesus Christ. The Church sees marriage as "a union according to Divine and human law," 
that is, not only according to temporary rules established by the people themselves, but also according to eternal laws created by God.

Unfortunately,

Christian dogmas are interpreted in a distorted way. For example, in 2008, US President B. Obama claimed, "Marriage is possible only between a man and a woman, because God unites", but a little later, he radically changed his position, referring to the "golden rule" (the concept that Christ taught in Matthew 7:12), which forced him to accept the so-called gay marriage. Then, is homosexual marriage the "golden rule" for marriage?

If we do not want human race to fall like Sodom and Gomorrah because of its depravity, we should radically change our attitude to the most ancient social institution - the family and the marriage.

\section{Literature review}

Currently, not many researchers have explored this issue. There have been no monographs published either by international or Russian scholars. There are several scientific papers and notes presenting philosophical positions of scientists.
Among international scholars exploring the problems of same-sex marriage we should mention G. Herek, a psychologist by training, who is mainly engaged in studying the psychological orientation of persons in same-sex marriage. In one of his well-known works, "Legal recognition of same-sex relationships in the United States: A social science perspective," G. Herek states that "Whether and how civil society should recognize committed relationships between same-sex partners has become a prominent, often divisive, policy issue. ... same-sex and heterosexual relationships do not differ in their essential psychosocial dimensions; that a parent's sexual orientation is unrelated to her or his ability to provide a healthy and nurturing family environment; and that marriage bestows substantial psychological, social, and health benefits. ... same-sex couples and their children are likely to benefit in numerous ways from legal recognition of their families, and providing such recognition through marriage will bestow greater benefit than civil unions or domestic partnerships. Trends in public opinion toward greater 
support for legal recognition of same-sex couples are discussed" (Herek, 2006).

In their scientific work "Observing gay, lesbian and heterosexual couples' relationships: Mathematical modeling of conflict interaction," J. Gottman and R. Levenson, like their colleague from California, solely focus on the psychological basis of the relationship of spouses in such marital and family relationships. The conclusion that the scientists came to is contradictory. According to them, "Two samples of committed gay and lesbian cohabiting couples and two samples of married couples (couples in which the woman presented the conflict issue to the man, and couples in which the man presented the conflict issue to the woman) engaged in three conversations: (1) an events of the day conversation (after being apart for at least 8 hours), (2) a conflict resolution conversation, and (3) a pleasant topic conversation (Gottman, Levenson, 2003)."

M. Trandafir (2014) conducted a rather interesting study regarding the impact on the institute of the family from the legalization of same-sex marriages. It is well-known that the first state to legalize same-sex marriage was the Netherlands (1998). M. Trandafir concluded that the legalization of samesex marriage entailed the transformation of the institution of marriage from a union of a man and a woman into a status similar to "daily plebiscite" (Trandafir, 2014). S. Titshaw (2012) proved that civil same-sex marriage appeared more appealing than starting a family.

In Russian science, only a few researchers, mainly of a specific political and sociological orientation, explore such unions. For example, scientists O.B. Bozhkov and T.Z. Protasenko (2012) conducted a sociological study aimed at identifying the causes of nontraditional family relationships. In their opinion, the main reason is the increasing popularity of this kind of unions and political reasons. Russian scientists, unlike their Western counterparts, have a negative attitude to these new-fangled Western phenomenon, linking it with a drop in the birth rate, a demographic catastrophe, and a fall in the family values. Thus, the presented analysis of the positions of Western and Russian scientists indicates that the problems considered in this article have not been fully explored since 
it is wrong to study the phenomenon of non-traditional marriages only from the socio-political and psychological perspective. This issue has many aspects and is connected with the interests of not only an individual or a group of people, but also the whole society and the state.

\section{Materials and methods}

In this research, we applied the following types of analysis: diachronous and synchronous, internal and external comparison, formal legal and sociological methods, as well as dialectical methods of scientific knowledge: analysis, abstraction, induction, deduction, hypothesis, analogy, and synthesis. The paper combines theoretical and empirical information.

\section{Results}

This research topic is quite controversial since people have very different opinions on this issue. To obtain experimental data, we took part in the Seventh International Youth Forum "Moral Imperatives in Law, Science, Education, and Culture", which was held on May 24, 2019 at the Belgorod State University (Belgorod, Russia). Our experiment aimed to obtain the data necessary to develop a certain position on the legalization of non-traditional marriages in Russia. During the presentation, the conference participants were invited to take part in a short sociological survey answering the following questions:

- What is your attitude to the institution of the family (do you support civil marriage/ cohabitation)?

- Do you support nontraditional types of sexual relations (yes/no/don't know)?

- Do you personally know any people belonging to non-traditional families (yes/no/I do not know)?

- In your opinion, should persons in non-traditional families be prosecuted (yes/no/ I do not know)?

The total number of the respondents was 70, and their age varied from 18 and older. As for their social status, the respondents were students, teachers, candidates and doctors of sciences, representatives of religious groups, psychologists, judges, administrative and management personnel. For more accurate presentation of the data obtained, we 
created several pie charts and drew

certain conclusions based on them.

\section{The share of the respondents supporting civil marriage/cohabitation}

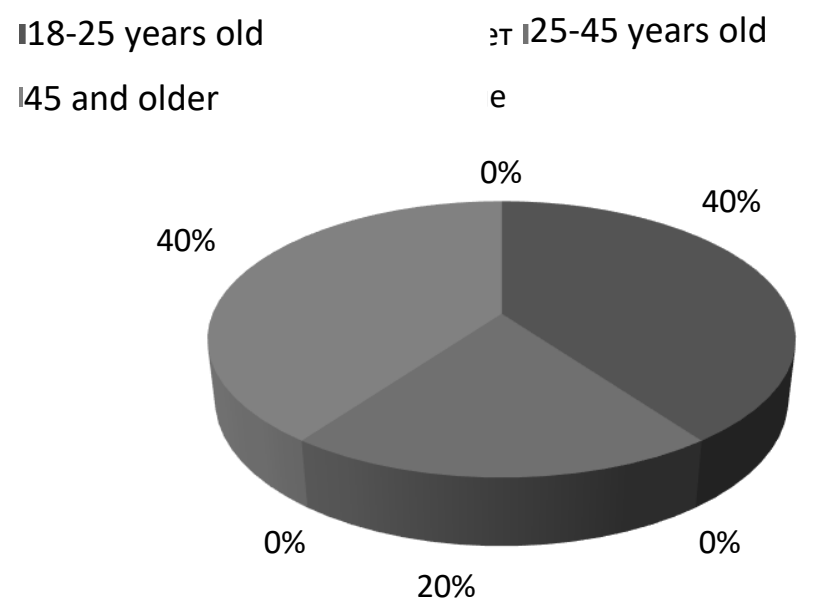

Chart 1. The share of the respondents supporting civil marriage/cohabitation 


\section{The share of the respondents supporting non-traditional types of sexual relations}

-18-25 years old

$\tau \square 25-45$ years old

$\square 45$ and older

$$
?
$$

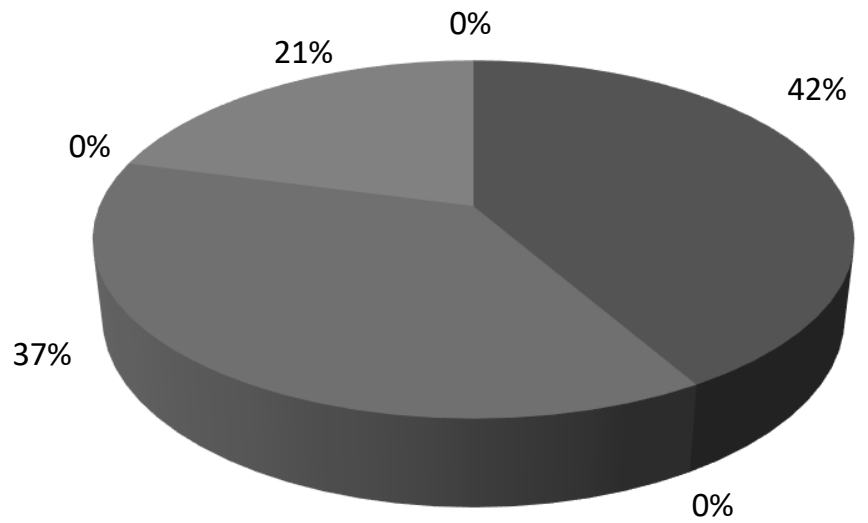

Chart 2. The share of the respondents supporting non-traditional types of sexual relations

\section{The share of the respondents who personally know representatives of non- traditional families}

18-25 years old

145 and older যт $125-45$ years old

e

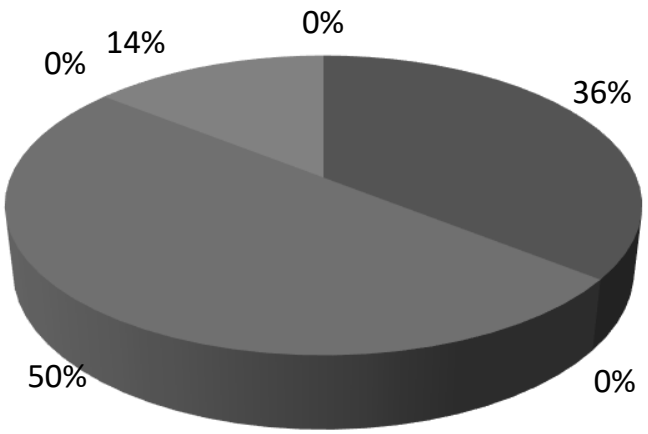

Chart 3. The share of the respondents who personally know representatives of non-traditional families 


\section{The share of the respondents who do not think that representatives of non-traditional families should be prosecuted}

\author{
118-25 years old \\ 145 and older
}

эт I25-45 years old

e

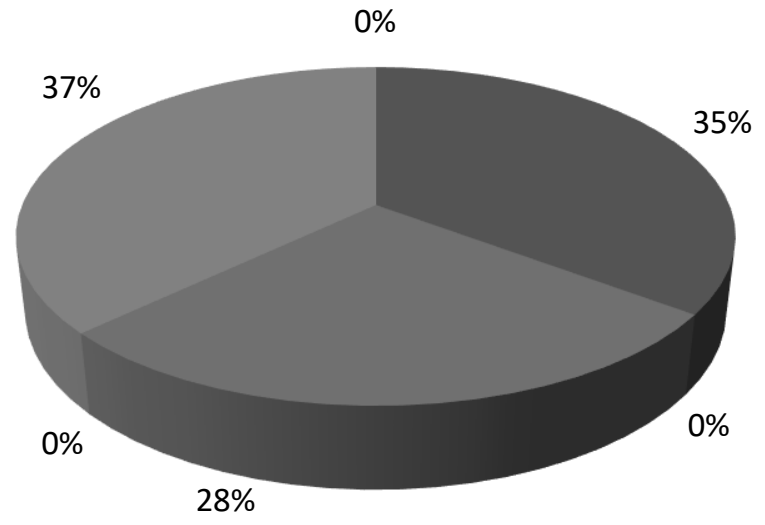

วT

Chart 4. The share of the respondents who no to think that representatives of non-traditional families should be prosecuted
These simple questions caused a storm of indignation among the representatives of the scientific community and students since, so to speak, the respondents divided into two groups: let us call the first one "students" and the second - "scientists". The former defended the legal status and legalization of same-sex unions in the state and did not see anything bad in them. The students considered this the norm of the modern time and a personal choice of the individual. The scientists (doctors of sciences, associate professors, and the representatives of the Orthodox Church) tried to show to the younger generation that the legalization and development of non-traditional marriages and family relations in Russia would lead to the collapse of the institution of the family and the subsequent destruction of the state due to the transformation of national traditions. We drew the following conclusions from the experiment. 
1. People aged from 18 and to 45 support such a form of marriage and family relations as cohabitation and do not oppose non-traditional marriages.

2. Non-traditional marriages were supported by young Russians. Currently, the youth is experiencing the transformation of traditional family values aimed at the destruction of gender roles in the family.

3. The younger generation to some extent supports the institution of cohabitation, recognizing non-traditional types of sexual relations. They are familiar with such forms of nontraditional marriages as, for example, partner swapping.

4. The students strongly disagreed with the persecution of persons creating non-traditional marriages, providing examples from life and the consequences of such actions. For instance, they mentioned Alan Matheson Turing, an English mathematician, who for his homosexuality was subjected to forced hormone therapy for suppressing libido, which led to his suicide by cyanide poisoning.

Thus, having carried out this small study and having obtained certain results, we identified the ideological position of the representatives of young Russians, which confirms the relevance of the research topic chosen.

\section{Discussion}

This article considers one of the oldest institutions -the family and marriage. Non-traditional marriages are the plague of the 21 st century that lead to the degradation of marriage as a legal and social institution, with subsequent fading away over time, since the main gender mission of human is lost. By legalizing same-sex marriages, legislators deliberately facilitate the selfdestruction of humankind, resulting in transhumanization of society. At present, the legalization of same-sex marriages in Russia seems hardly possible.

In this study, we examined the types and forms of marriage in the modern world and classified them. Nontraditional marriages are considered deviations from Christian norms. Having analyzed the church dogma, we demonstrated the anti-religious nature of such unions. According to the Bible, marriage and family are the remnants of paradise on earth. This is an oasis that was not destroyed by the global 
cataclysms, desecrated by the sin of the first people, or was not swept away by the waves of the Great Flood. This shrine should be kept clean. All this is possible if Russian legal norms regulating marriage and family relations incorporate the church dogma. The Russian Orthodox Church is a fierce opponent not only of same-sex marriage, but also the recognition of the rights of citizens with non-traditional sexual orientation. Moreover, the position of the Russian state on homosexuality and same-sex marriage is strongly negative, which also has a powerful socializing effect.

Nowadays Russian youth is experiencing the transformation of traditional family values aimed at the destruction of gender roles in the family. In our opinion, the continuous spontaneous and deliberate destruction of the patriarchal family in the Russian Federation as the basis of the microsocial component of human society currently manifests itself through:

1. Negative demographic consequences that undermine the concept of what is permissible and what is forbidden, blurring the differences between normal and deviant behavior.
2. Decreasing effectiveness of anti-criminal moral and psychological factors in the situation when the relationships between sexes and generations are being distorted.

3. The weakening of the "preventive actions" of the Orthodox Church among the Russian youth.

\section{Conclusion}

Having analyzed the types of marriage and family relations and partnerships, we systematized them according to the following criteria: by the number of participants in such a union: monogamy and polygamy; by the method of marriage registration: church, civil, and cohabitation; by gender of partners: heterosexual and homosexual; according to the method of choosing a partner: endogamy, levirate, sororate, exogamy, arranged, and egalitarian marriage.

Non-traditional marriage is a relationship that deviates from generally accepted standards "the man and the woman," varying in the number of participants, their gender, the method of marriage registration and the method of choosing a partner in order to satisfy sexual interests and needs. In our 
opinion, to avoid unnecessary emotions and disputes on the issue of same-sex relationships, it should be recognized at the legal and political level that the family consisting of a man and a woman is the norm. Everything else, not only homosexuality, but also any fornication and adultery should be considered a deviation from the norm and detrimental. The state policy should not see these as normal. If people are not stimulated to destroy this moral constant and accept the deviation as a norm, then there will be no heated debate and strong emotions about this issue.

Having analyzed the opinions of international and Russian scholars, religious norms, and the sociological data obtained, we can conclude that a change in national legislation regarding the preservation of the institution of the family is inevitable, it is just a matter of time, one or maybe two decades. The family is the foundation of the state, national identity, and cultural development. Without a family in its traditional sense, it is impossible to preserve traditions and to pass them on from one generation to another. Therefore, it is imperative for us and our legislators to seriously consider the
838 legalization of the concept of nontraditional marriages so that they are prohibited and the individuals who are looking to enter into such marriages are persecuted, since these newfangled Western trends are aimed at the destruction of state values and the inexorable degradation of the state itself.

\section{References}

Bozhkov, O.B., Protasenko, T.Z. (2012), "Same-sex marriage is a mostly political problem", Telescope: Journal of Sociological and Marketing Research, 1, $35-42$.

Flavius, I. (1544), Jewish Antiquities 3.12: 1 .

Gottman, J., Levenson, R. (2003), "Observing gay, lesbian and heterosexual couples' relationships: Mathematical modeling of conflict interaction", Journal of Homosexuality, 45(1), 65-91.

Herek, G. (2006), "Legal recognition of same-sex relationships in the United States: A social science perspective", American Psychologist, 61(6), 607-621. Is homosexual marriage the "golden rule" for marriage? Retrieved from: http://www.origins.org.ua/page.php?id_ story $=1605 \#$ ixzz4ZaWmCDao 
Kochetkov, I. (2013), “Expert: Russia will have to recognize same-sex marriage or "say goodbye" to the Council of Europe", retrieved from: http://www.rosbalt.ru/piter/2013/04/10/ 1116227.html

Moscow Patriarchate (2000), Basics of the social concept of the Russian Orthodox Church. Department for External Church Relations of the Moscow Patriarchate. Moscow: "1st Model Moscow Printing House".

Novikov, A. (2008), "Family 2020", retrieved from: http://echo.msk.ru/programs/futureback/ 549062-echo/

Pravoslavie.ru, official website http://www.pravoslavie.ru/

Putin, V.V. (2013), "Putin opposes attempts to equalize traditional and same-sex marriage", retrieved from: https://ria.ru/valdaiclub_anniversary_se ssion/20130919/964434704.html Titshaw, S. (2012), "The Reactionary Road to Free Love: How DOMA, State Marriage Amendments and Social Conservatives Undermine Traditional Marriage", West Virginia Law Review, 115(1).

Trandafir, M. (2014), "The effect of same-sex marriage laws on different-sex marriage: Evidence from 839

Netherlands", Demography, 51, 317-340

Yakovleva, E. (2013), "Shutting the door on same-sex marriage", Russian

Newspaper, May 22, 2013 